\title{
Malyngamide F Possesses Anti-Inflammatory and Antinociceptive Activity in Rat Models of Inflammation
}

\author{
Zhuocheng Li $\mathbb{D}^{1},{ }^{1}$ Lei Zhang $\mathbb{D}{ }^{2}$ and Zhichao Zhao ${ }^{3}{ }^{3}$ \\ ${ }^{1}$ Department of Anesthesiology, Heilongjiang Provincial Hospital, No. 82 Zhongshan Road, Xiangfang District, Harbin City, \\ Heilongjiang Province 150036, China \\ ${ }^{2}$ Department of Anesthesiology, Harbin Chest Hospital, No. 417 Xianfeng Road, Daowai District, Harbin City, \\ Heilongjiang Province 150026, China \\ ${ }^{3}$ Operation Room, Heilongjiang Provincial Hospital, No. 82 Zhongshan Road, Xiangfang District, Harbin City, \\ Heilongjiang Province 150036, China
}

Correspondence should be addressed to Zhichao Zhao; zhaozhichao320@163.com

Received 12 April 2021; Accepted 9 June 2021; Published 18 June 2021

Academic Editor: Giustino Varrassi

Copyright ( 12021 Zhuocheng Li et al. This is an open access article distributed under the Creative Commons Attribution License, which permits unrestricted use, distribution, and reproduction in any medium, provided the original work is properly cited.

Objective. Inflammation and pain are involved in the pathophysiology of various clinical conditions. This investigation aims to probe the analgesic and anti-inflammatory activity of Maltoamide F. Methods. The possible toxicity of Maltoamide F was evaluated by an acute toxicity test. To assess the anti-inflammatory and antinociceptive effects of Maltoamide $\mathrm{F}$ on rats, the models of carrageenan-caused paw edema, xylene-induced ear edema, arachidonic-acid- (AA-) induced ear edema, formalin-caused plantar edema, and cotton-pellet-induced granuloma were established. Levels of TNF- $\alpha$, PGE-2, and IL- 6 were detected by enzyme-linked immunosorbent assay (ELISA). Results. Maltoamide F was safe at oral doses of $1-10 \mathrm{mg} / \mathrm{kg}$ for rats. Maltoamide F (1 mg/kg, $5 \mathrm{mg} /$ $\mathrm{kg}$, and $10 \mathrm{mg} / \mathrm{kg}$ ) notably reduced carrageenan-induced edema percentage of paws in rats and decreased levels of PGE-2, IL-6, and TNF- $\alpha$ in homogenates of foot tissues. Maltoamide F $(1 \mathrm{mg} / \mathrm{kg}, 5 \mathrm{mg} / \mathrm{kg}$, and $10 \mathrm{mg} / \mathrm{kg})$ reduced levels of PGE-2, IL-6, and TNF- $\alpha$ in foot tissues of formalin-induced rats. Maltoamide F $(1 \mathrm{mg} / \mathrm{kg}, 5 \mathrm{mg} / \mathrm{kg}$, and $10 \mathrm{mg} / \mathrm{kg})$ repressed AA-induced increase of ear thickness in rats and reduced levels of PGE-2, IL-6, and TNF- $\alpha$ in homogenates of ear tissues. Maltoamide F (1 mg/kg, $5 \mathrm{mg} / \mathrm{kg}$, and $10 \mathrm{mg} / \mathrm{kg}$ ) reduced xylene-induced weight of ear edema in rats and reduced levels of PGE-2, IL-6, and TNF- $\alpha$ in homogenates of ear tissues. Maltoamide F ( $1 \mathrm{mg} / \mathrm{kg}, 5 \mathrm{mg} / \mathrm{kg}$, and $10 \mathrm{mg} / \mathrm{kg}$ ) reduced levels of PGE-2, IL-6, and TNF- $\alpha$ in homogenates of cotton ball granuloma of cotton-pellet-induced rats. Conclusions. Maltoamide F possessed anti-inflammatory and analgesic activity in inflammatory models of rats.

\section{Introduction}

Inflammation is a natural response of the body to detrimental stimuli, which occurs through incremental movement of leucocytes from blood to damaged tissues [1]. It is developed by the release of cytokines, bradykinin, and histamine $[2,3]$. Swelling, redness, heat, and pain are the major features of inflammation $[4,5]$. The controlled inflammation can remove the irritants, eliminate invasive organisms, and promote the repair of damaged tissues $[6,7]$. However, uncontrolled inflammation leads to organ dysfunction and tissue damage, thereby causing inflammatory diseases [8-10]. At present, common treatments used to treat inflammatory diseases are nonsteroidal and steroidal drugs, but side effects of these drugs limit their clinical applications $[11,12]$. Thence, there is an urgent need to search new anti-inflammatory agents with less toxicity and good efficacy.

Malyngamides are a type of metabolite from L. majuscula $[13,14]$. Structurally, malyngamides are composed of an assumed amino-acid-derived head and a methoxylated fatty acid tail [15]. Since 1978, over 30 different malyngamides have been isolated, which have a wide range of biological properties such as antimicrobial, antimycobacterial, and anti-inflammatory properties [16-21]. Importantly, several members of malyngamides are 
uncovered to possess anti-inflammatory effects [22, 23]. For instance, Villa et al. have unveiled that Malyngamide F acetate displays anti-inflammatory activity in the NO assay with no cytotoxicity at the concentrations tested [22]. Malloy et al. have revealed that Malyngamide 2 shows anti-inflammatory activity in LPS-induced macrophage cells [23]. However, the anti-inflammatory role of Malyngamide $\mathrm{F}$ has not been verified in animal models.

Hereon, we intended to determine the toxicity of Malyngamide $\mathrm{F}$ in rats and further assessed the anti-inflammatory activity and analgesic activity of Malyngamide F in rat models of inflammation.

\section{Materials and Methods}

2.1. Animals. Male Sprague Dawley (SD) rats (weighing 210-260 g) were bought from Esebio (Shanghai, China). All rats were housed in a controlled environment with a temperature of $21 \pm 2^{\circ} \mathrm{C}$ and a cycle of $12 \mathrm{~h}$ light/dark. Before the experiment, rats had free access to water and food. This investigation was approved by the Animal Care and Use Committee of our hospital, and all experiments were executed on the basis of the National Institutes of Health Guide for the Care and Use of Laboratory Animals. Each experimental group is composed of 6 rats, and each rat was used only once in our experiments.

2.2. Drugs and Reagents. Indomethacin F was bought from Chengdu Pharmaceutical Factory (Chengdu, China), and carrageenan, formalin, xylene, and arachidonic acid (AA) were purchased from Sigma Chemical Co. (St. Louis, MO, USA).

2.3. Collection of Materials. The marine cyanobacterium Lyngbya majuscula was collected from Kahala Beach, Oahu island, Hawaii, and stored at $-20^{\circ} \mathrm{C}$ until workup.

2.4. Extraction and Isolation. For obtaining $663 \mathrm{mg}$ of cytotoxic crude organic extract, cyanobacterium L. majuscula (19.3 g) was isolated by $\mathrm{CH}_{2} \mathrm{Cl}_{2}: \mathrm{MeOH}(2: 1, \mathrm{v} / \mathrm{v})$. To obtain nine fractions, this extract was fractionated via vacuum liquid chromatography (VLC). Fractions (5, 6, and 7) displayed cytotoxic impacts and then were further explored. To obtain two definite fractions, fraction 5 was resolved with RP-HPLC. Then, a second chromatography of the first fraction generated $24.6 \mathrm{mg}$ of 8 -O-acetyl-8-epi-malyngamide C (1). Further separation of VLC fraction 6 led to additional compound 1 (9.5 $\mathrm{mg}$ ) and an indivisible mixture of malyngamide $\mathrm{H}$ (6) and $\mathrm{K}$ (8). Next, reversed-phase HPLC of VLC fraction 7 generated $1.9 \mathrm{mg}$ 6-O-acetyl malyngamide $\mathrm{F}$ (5), $0.8 \mathrm{mg}$ compound 3 , and $1.1 \mathrm{mg}$ inseparable mixture of malyngamide $\mathrm{H}(6)$ and $\mathrm{K}(8) .{ }^{1} \mathrm{H}$ NMR profiling of all VLC fractions indicated that fraction 8 also included a malyngamide-type metabolite. Thus, fraction 8 was first subjected to $\mathrm{C}_{18}$ HPLC, and those materials were purified through RP-HPLC to obtain malyngamide J (7).
2.5. Drug Treatment. The rats in three groups $(n=6)$ were given Maltoamide $\mathrm{F}(1,5$, and $10 \mathrm{mg} / \mathrm{kg})$ by intubation. Rats in the positive control group $(n=6)$ were given indomethacin $(5 \mathrm{mg} / \mathrm{kg})$, and rats in the negative control group $(n=6)$ were treated with $1 \% \mathrm{EtOH}$. All rats were given drugs at a dose of $10 \mathrm{~mL} / \mathrm{kg}$ according to their body weight.

2.6. Acute Toxicity Test. The toxicity of Malyngamide F was evaluated by the acute toxicity test. Rats were treated via oral administration of extracts in different doses, and the dose was adjusted according to rat response [24]. The maximum dose given to each rat was $50 \mathrm{mg} / \mathrm{kg}$, and rats in the control group were treated with distilled water. All rats were observed within 7 days.

2.7. Anti-Inflammatory Experiments. In the paw edema test [25], $0.1 \mathrm{~mL}$ carrageenan (1\%) in normal saline was injected into the right hind paws of rats to induce inflammation. At 0 , $0.5,1,2,3,4$, and $6 \mathrm{~h}$ after carrageenan injection, the paw volume was gauged with a paw edema detector (Shandong Academy of Medical Science Device Station, Shandong, China). Rats were orally administered either indomethacin or Malyngamide F before $0.5 \mathrm{~h}$ of carrageenan injection. The calculation of edema percentage was as follows: edema percentage $(\%)=\left(V_{t}-V_{0}\right) / V_{0} \times 100$, where $V_{0}$ is the volume before carrageenan injection and $V_{t}$ is the volume at $t$ h after carrageenan injection.

In the plantar edema test [26], $20 \mu \mathrm{L}$ formalin (2\%) was injected into the right hind paws of rats to induce inflammation [27]. Before formalin injection for $1 \mathrm{~h}$, Maltamide F or indomethacin was orally administered for 7 consecutive days. Mean increase of paw volume was gauged on the first and seventh day, and the percent inhibition was calculated with the following formula [28]: inhibition $(\%)=\left(V_{c}-V_{t}\right) /$ $V_{c} \times 100$, where $V_{c}$ is the mean increase in edema in the control group and $V_{t}$ is mean increase in edema in treated groups.

In the ear edema test [29], AA was dissolved in acetone at a concentration of $100 \mathrm{mg} / \mathrm{mL}$, and then, $20 \mu \mathrm{L} \mathrm{AA}(2 \mathrm{mg} /$ ear) was used to treat each rat on both surfaces of an ear. At 30 min before AA induction, Maltamide F and indomethacin were dissolved in ethanol and were suspended with $1 \%$ polyoxyethylene sorbitan monooleate (Tween 80, Tokyo Kasei Chemical Industry, Japan). After AA induction for $1 \mathrm{~h}$, ear edema was gauged by using a dial thickness gauge (Ozaki Factory, Japan).

In the xylene-induced ear edema assay [30], rats were treated with Maltamide F and indomethacin for $1 \mathrm{~h}$. Subsequently, the surface of the right ear was treated by $30 \mu \mathrm{L}$ xylene for $30 \mathrm{~min}$, and then, both ears were removed. Punch biopsy specimens of a $6 \mathrm{~mm}^{2}$ ear were collected and weighed. The weight of ear edema was calculated via subtracting the weight of the left ear from that of the right.

In the cotton pellet granuloma test [31], rats were anaesthetized via ethyl ether, and then, the back skin was scraped and disinfected with $70 \%$ ethanol. An incision was generated in the lumbar region. Next, a subcutaneous tunnel was generated and a cotton pellet was placed in the scapular 
region. After surgery, each rat was intramuscularly injected with benzathine penicillin $(60,000 \mathrm{IU})$. The rats in each group were treated with maltamide $\mathrm{F}$ or indomethacin for seven days. On the $8^{\text {th }}$ day, the rats were sacrificed and the cotton pellets were removed through surgery. After removing extraneous tissues, moist pellets were weighed (wet weight). Then, the pellets were dried at $90^{\circ} \mathrm{C}$ for $3 \mathrm{~h}$, and the dried pellets were weighed (dry weight).

2.8. Enzyme-Linked Immunosorbent Assay (ELISA). Ear tissues, foot tissues, and cotton ball granuloma were collected and then homogenized in PBS containing $1 \%$ protease inhibitor. Afterwards, the homogenates were centrifuged at $10,000 \mathrm{~g}$ and placed at $4^{\circ} \mathrm{C}$ for $30 \mathrm{~min}$. Finally, the content of tumor necrosis factor-a (TNF- $\alpha$ ), interleukin-6 (IL-6), and PGE-2 (a pain-related factor) was measured by using Quantikine ELISA Kits (R\&D Systems, Abingdon, UK). The optical density was examined at $450 \mathrm{~nm}$ using a microplate reader (Molecular Devices, Sunnyvale, CA).

2.9. Statistical Analysis. SPSS 21.0 software (IBM Corp, Armonk, NY, USA) was employed to analyze data. All results were exhibited by means \pm standard deviation. Differences among multigroups were compared with one-way analysis of variance (ANOVA), followed by Tukey's multiple comparisons. $P<0.05$ indicated a statistically significant difference.

\section{Results}

3.1. Maltoamide F Is Safe at Oral Doses of 1-10 mg/ $\mathrm{kg}$ for Rats. To determine the oral dose of Maltoamide F, an acute toxicity test was implemented in rats. As displayed in Figure 1, the maximum oral dose of Maltoamide F was $50 \mathrm{mg} /$ $\mathrm{kg}$, and no death was observed during the evaluation period of $7 \mathrm{~d}$. Therefore, Maltoamide $\mathrm{F}$ is safe at oral doses of $1-10 \mathrm{mg} / \mathrm{kg}$ for rats.

3.2. Maltoamide F Alleviated Carrageenan-Induced Paw Edema and Inflammation in Rats. For exploring whether Maltoamide F made anti-inflammatory impacts on rats, we performed the following anti-inflammatory assays. We found that Maltoamide F distinctly reduced edema percentage of rat paws as opposed to the control group, which persisted for $6 \mathrm{~h}(P<0.05$, Figure 2(a)). Meantime, we discovered that $1 \mathrm{mg} / \mathrm{kg}$ Maltoamide $\mathrm{F}(P<0.05), 5 \mathrm{mg} / \mathrm{kg}$ Maltoamide $\mathrm{F}(P<0.01)$, and $10 \mathrm{mg} / \mathrm{kg}$ Maltoamide $\mathrm{F}$ $(P<0.001)$ markedly decreased the levels of PGE-2, IL-6, and TNF- $\alpha$ in comparison to the control group (Figures 2(b)-2(d)).

\subsection{Maltoamide F Mitigated Formalin-Induced Inflammation} in Rats. Besides, we discovered that the percentage inhibition of $1 \mathrm{mg} / \mathrm{kg}$ and $5 \mathrm{mg} / \mathrm{kg}$ Maltoamide $\mathrm{F}$ was lower than that of $5 \mathrm{mg} / \mathrm{kg}$ indomethacin (Figure $3(\mathrm{a})$ ). The $10 \mathrm{mg} / \mathrm{kg}$ Maltoamide $\mathrm{F}$ presented a comparable effect when compared to $5 \mathrm{mg} / \mathrm{kg}$ indomethacin (Figure 3(a)). Injection of

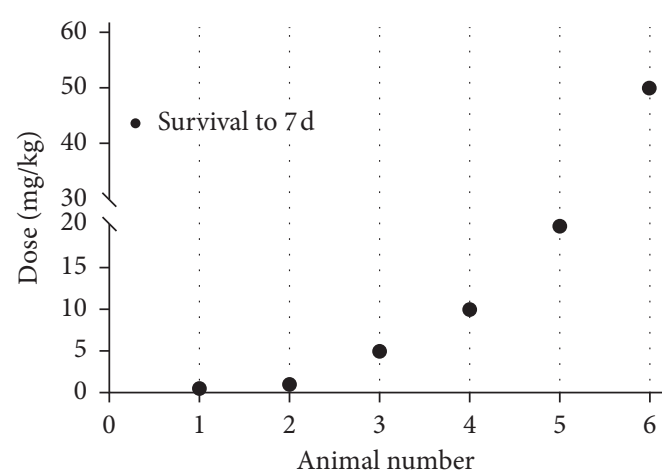

Figure 1: Maltoamide F is safe for rats at oral doses of $1-10 \mathrm{mg} / \mathrm{kg}$, the acute toxicity test of Maltoamide $\mathrm{F}$ in rats.

$1 \mathrm{mg} / \mathrm{kg} \quad(P<0.01), \quad 5 \mathrm{mg} / \mathrm{kg} \quad(P<0.01), \quad$ and $\quad 10 \mathrm{mg} / \mathrm{kg}$ $(P<0.001)$ Maltoamide $\mathrm{F}$ distinctly reduced the levels of TNF- $\alpha$, PGE-2, and IL- 6 in homogenates of foot tissues (Figures 3(b)-3(d)).

3.4. Maltoamide F Lightened AA-Induced Ear Edema and Inflammation in Rats. In contrast to the control group, $1 \mathrm{mg} / \mathrm{kg} \quad(P<0.01), \quad 5 \mathrm{mg} / \mathrm{kg} \quad(P<0.001)$, and $10 \mathrm{mg} / \mathrm{kg}$ $(P<0.001)$ Maltoamide $\mathrm{F}$ repressed increase of ear thickness in rats (Figure $4(\mathrm{a}))$. Additionally, $1 \mathrm{mg} / \mathrm{kg}(P<0.01), 5 \mathrm{mg} /$ $\mathrm{kg}(P<0.01)$, and $10 \mathrm{mg} / \mathrm{kg}(P<0.001)$ Maltoamide $\mathrm{F}$ distinctly reduced levels of TNF- $\alpha$ and PGE-2, and the IL-6 level was also diminished by $1 \mathrm{mg} / \mathrm{kg}(P<0.01), 5 \mathrm{mg} / \mathrm{kg}$ $(P<0.001)$, and $10 \mathrm{mg} / \mathrm{kg}(P<0.001)$ Maltoamide $\mathrm{F}$ in homogenates of ear tissues of AA-induced rats (Figures 4(b)-4(d)).

3.5. Maltoamide F Alleviated Ear Edema and Inflammation Induced by Xylene in Rats. Compared with the control group, injection of $1 \mathrm{mg} / \mathrm{kg}, 5 \mathrm{mg} / \mathrm{kg}$, and $10 \mathrm{mg} / \mathrm{kg} \mathrm{Mal-}$ toamide $\mathrm{F}$ markedly reduced ear edema weight in xyleneinduced rats (Figure 5(a)). Moreover, $1 \mathrm{mg} / \mathrm{kg}(P<0.01)$, $5 \mathrm{mg} / \mathrm{kg}(P<0.001)$, and $10 \mathrm{mg} / \mathrm{kg}(P<0.001)$ Maltoamide $\mathrm{F}$ distinctly reduced levels of TNF- $\alpha$ and PGE-2, and the IL-6 level was also diminished by $1 \mathrm{mg} / \mathrm{kg}(P<0.01), 5 \mathrm{mg} / \mathrm{kg}$ $(P<0.01)$, and $10 \mathrm{mg} / \mathrm{kg}(P<0.001)$ Maltoamide $\mathrm{F}$ in homogenates of ear tissues of xylene-induced rats (Figures 5(b)-5(d)).

3.6. Maltoamide F Mitigated Cotton-Pellet-Induced Granuloma and Inflammation in Rats. Finally, it was demonstrated that the granuloma weight was significantly diminished by Maltoamide F $(1 \mathrm{mg} / \mathrm{kg}, 5 \mathrm{mg} / \mathrm{kg}$, and $10 \mathrm{mg} / \mathrm{kg}$ ) in cotton-pellet-induced rats (all $P<0.05$, Table 1). The levels of PGE-2, IL-6, and TNF- $\alpha$ were decreased by $1 \mathrm{mg} / \mathrm{kg}(P<0.01), 5 \mathrm{mg} / \mathrm{kg}(P<0.001)$, and $10 \mathrm{mg} / \mathrm{kg}$ $(P<0.001)$ Maltoamide $\mathrm{F}$ in homogenates of cotton ball granuloma tissues of cotton-pellet-induced rats (Figures 6(a)-6(c)). 


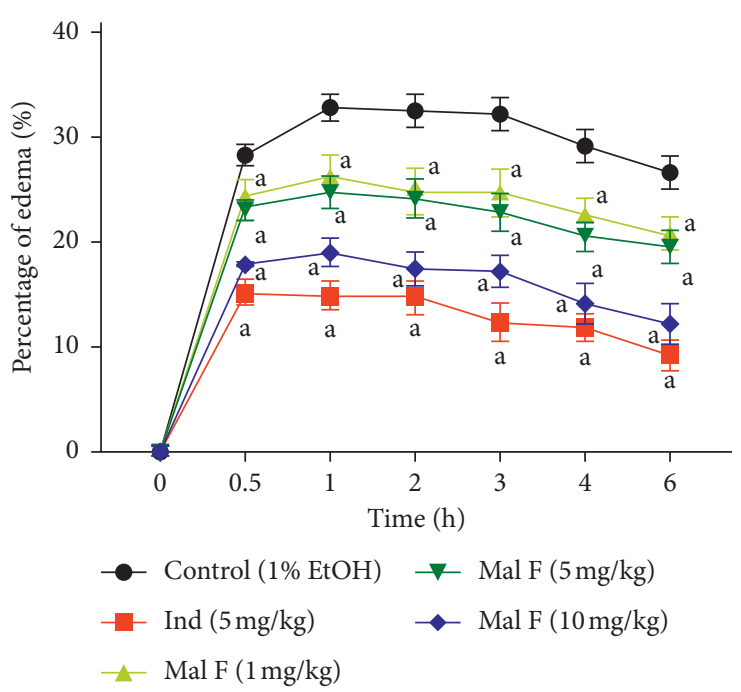

(a)

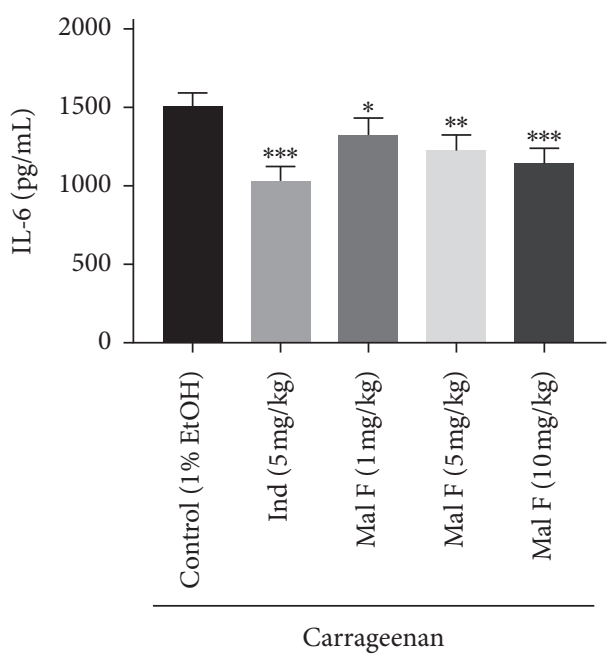

(c)

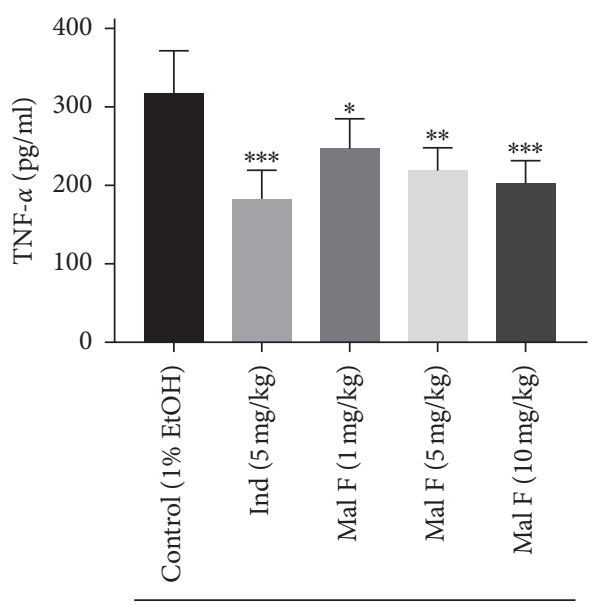

Carrageenan

(b)

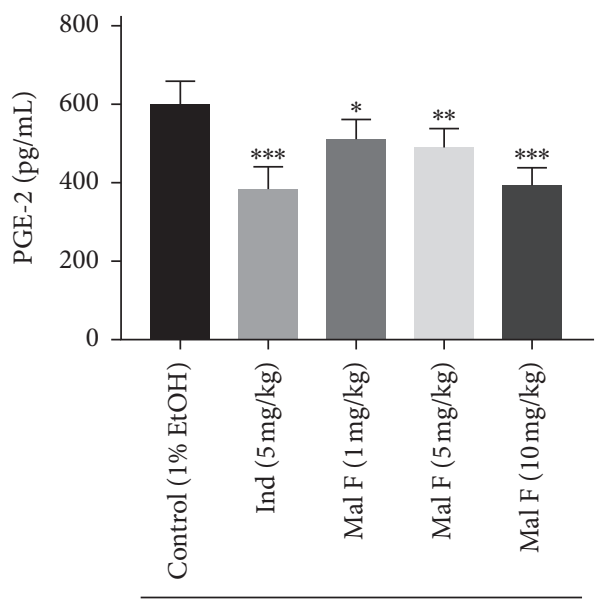

Carrageenan

(d)

FIgURE 2: Maltoamide F alleviated carrageenan-induced paw edema and inflammation in rats. (a) The effect of Maltoamide F on percentage of paw edema in carrageenan-induced rats. a: $P<0.05$ vs. control $(1 \% \mathrm{EtOH})$. (b) The level of TNF- $\alpha$ in homogenates of foot tissues was measured by ELISA. ${ }^{*} P<0.05,{ }^{* *} P<0.01$, and ${ }^{* * *} P<0.001$ vs. control ( $1 \%$ EtOH). (c) The level of IL- 6 in homogenates of foot tissues was measured by ELISA. ${ }^{*} P<0.05,{ }^{* *} P<0.01$, and ${ }^{* * *} P<0.001$ vs. control $(1 \% \mathrm{EtOH})$. (d) The level of PGE- 2 in homogenates of foot tissues was measured by ELISA. ${ }^{*} P<0.05,{ }^{* *} P<0.01$, and ${ }^{* * *} P<0.001$ vs. control $(1 \%$ EtOH $)$.

\section{Discussion}

Inflammation is defined as a part of the host defense system and caused by varied stimuli $[1,32]$. It is widely implicated in the progression of human diseases, thereby becoming the focus of scientific research $[33,34]$. Recent data from anti-inflammatory assays have indicated that malyngamides are active, and Malyngamide $\mathrm{F}$ acetate is the most potent malyngamide with minimal cytotoxicity [22]. Here, the result of the acute toxicity test displayed that the maximum oral dose of Maltoamide F was $50 \mathrm{mg} / \mathrm{kg}$, and it is safe at oral doses of $1-10 \mathrm{mg} / \mathrm{kg}$ for rats.

Additionally, the emerging literature has proved that malyngamides possess anti-inflammatory activity [22, 23]. For example, Villa et al. have suggested that Malyngamide F acetate shows anti-inflammatory activity in the NO assay [22]. Malloy et al. have revealed that Malyngamide 2 exerts an anti-inflammatory role in LPS-induced macrophage cells [23]. In the present study, our findings were as follows: (1) Maltoamide F notably reduced carrageenan-induced edema percentage of rat paws compared with the control group. (2) Maltoamide F suppressed increase of ear thickness compared with the control group in AA-induced rats. (3) In contrast to the control group, Maltoamide $\mathrm{F}$ reduced weight of ear edema in xylene-induced rats. (4) The granuloma weight was significantly diminished by Maltoamide $\mathrm{F}$ in cotton-pellet-induced rats. Based on these results, we inferred that Malyngamide $\mathrm{F}$ possessed anti-inflammatory potent in both rat models of inflammation. 


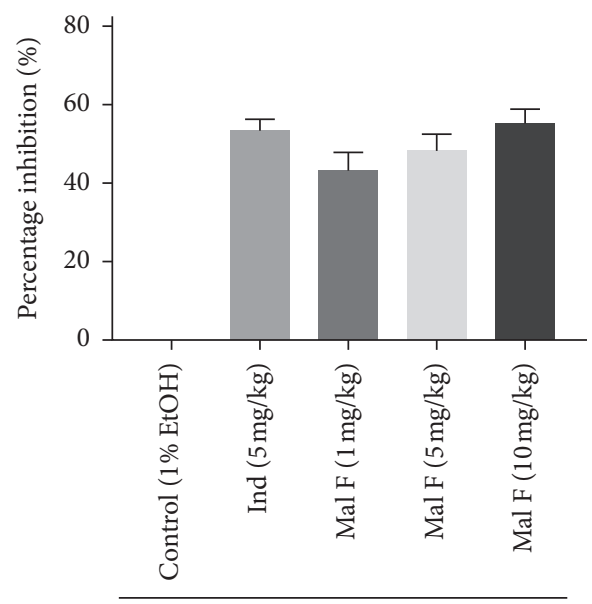

Formalin

(a)

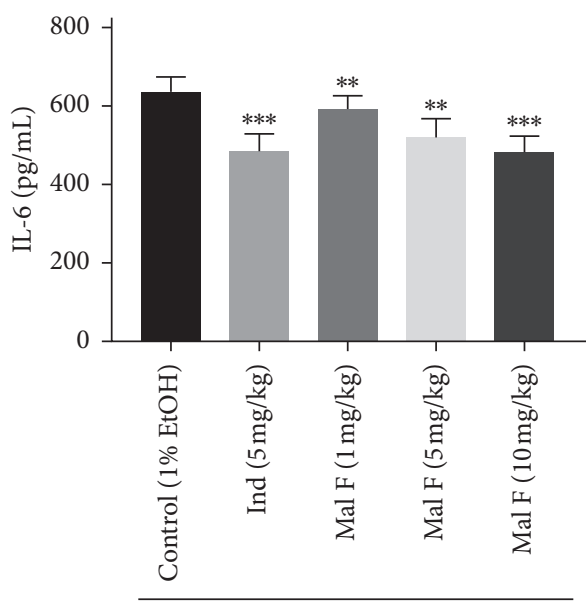

Formalin

(c)

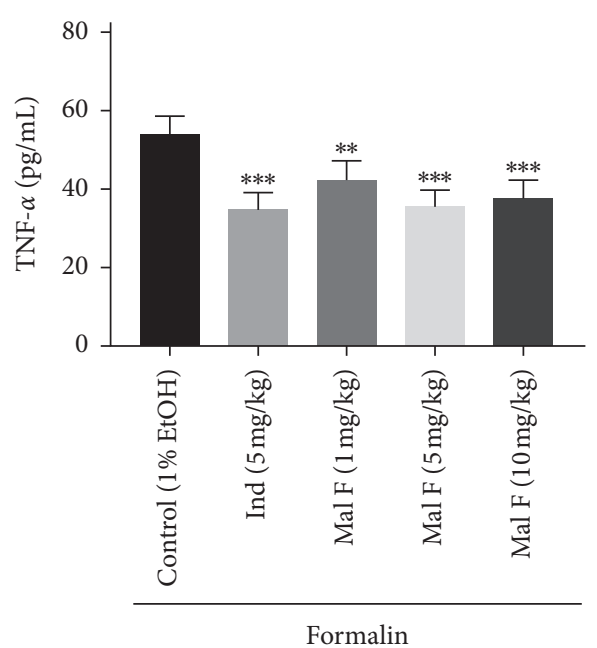

(b)

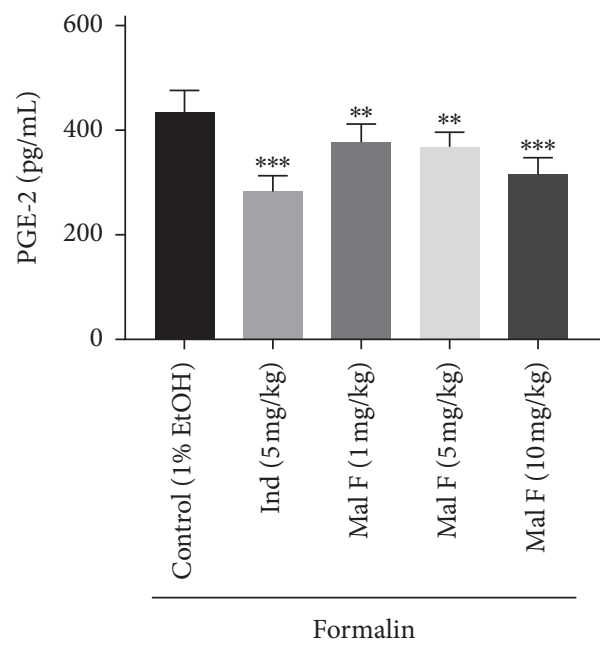

(d)

FIGURE 3: Maltoamide F mitigated formalin-induced inflammation in rats. (a) The effect of Maltoamide F on percentage inhibition in formalin-induced rats. (b) The level of TNF- $\alpha$ in homogenates of foot tissues was measured by ELISA. ${ }^{* *} P<0.01$ and ${ }^{* * *} P<0.001$ vs. control (1\% EtOH). (c) The level of IL-6 in homogenates of foot tissues was measured by ELISA. ${ }^{* *} P<0.01$ and ${ }^{* * *} P<0.001$ vs. control $(1 \%$ EtOH). (d) The level of PGE-2 in homogenates of foot tissues was measured by ELISA. ${ }^{* *} P<0.01$ and ${ }^{* * *} P<0.001 \mathrm{vs.} \mathrm{control} \mathrm{(1 \%} \mathrm{EtOH).}$

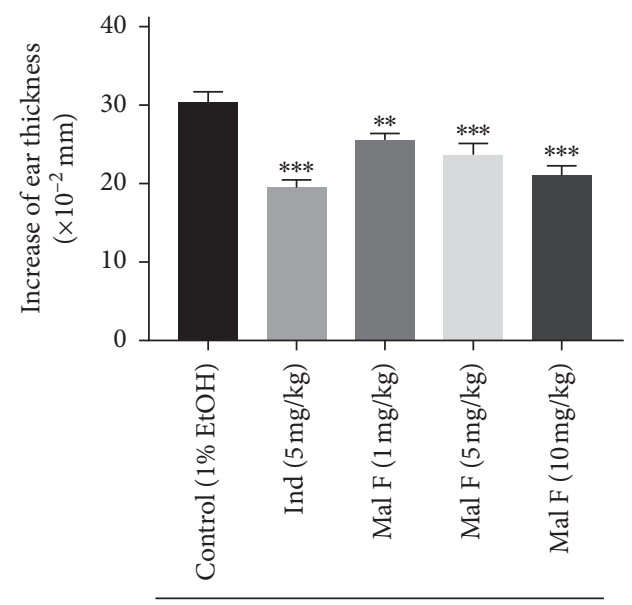

Arachidonic acid

(a)

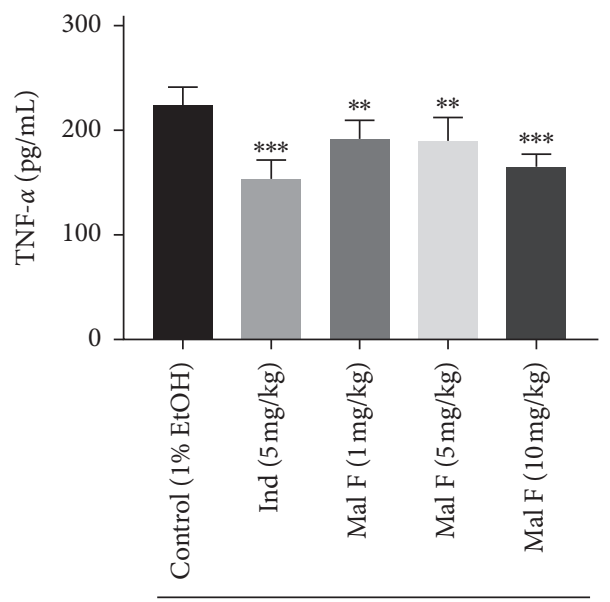

Arachidonic acid

(b)

FIGURE 4: Continued. 


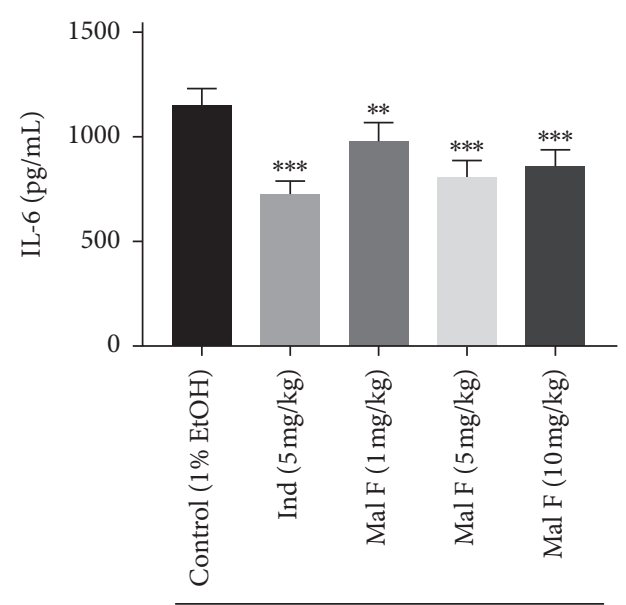

Arachidonic acid

(c)

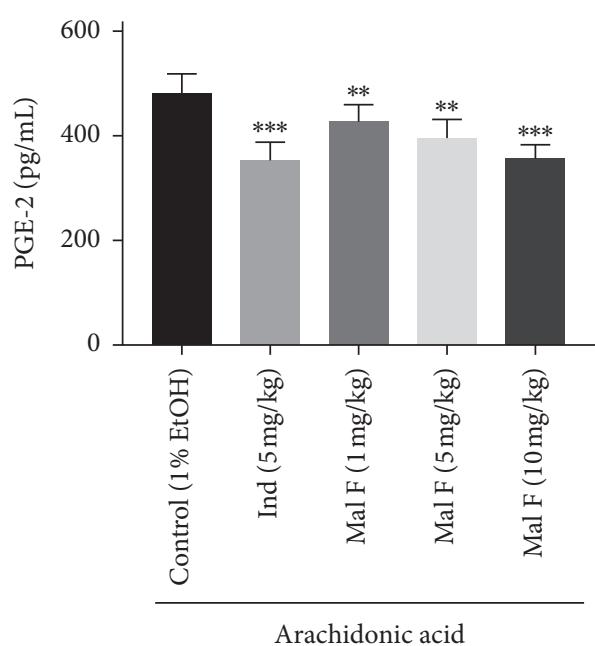

(d)

Figure 4: Maltoamide F lightened arachidonic-acid- (AA-) induced ear edema and inflammation in rats. (a) The effect of Maltoamide F on increase of ear thickness in AA-induced rats. ${ }^{* *} P<0.01$ and ${ }^{* * *} P<0.001$ vs. control (1\% EtOH). (b) The level of TNF- $\alpha$ in homogenates of ear tissues was measured by ELISA. ${ }^{* *} P<0.01$ and ${ }^{* * *} P<0.001$ vs. control (1\% EtOH). (c) The level of IL-6 in homogenates of foot tissues was measured by ELISA. ${ }^{* *} P<0.01$ and ${ }^{* * *} P<0.001$ vs. control $(1 \%$ EtOH). (d) The level of PGE-2 in homogenates of foot tissues was measured by ELISA. ${ }^{* *} P<0.01$ and ${ }^{* * *} P<0.001$ vs. control $(1 \% \mathrm{EtOH})$.

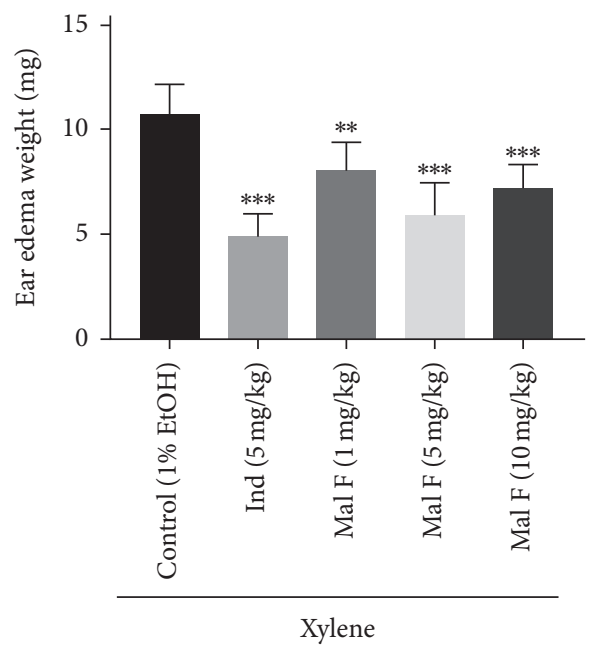

(a)

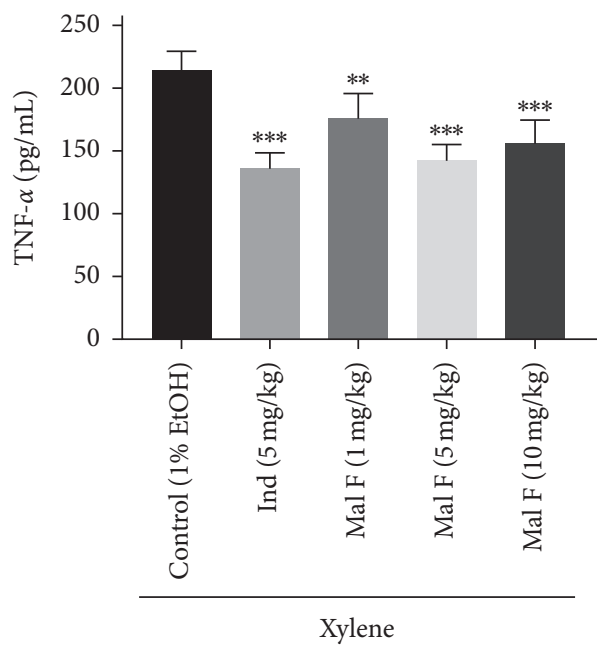

(b)

Figure 5: Continued. 


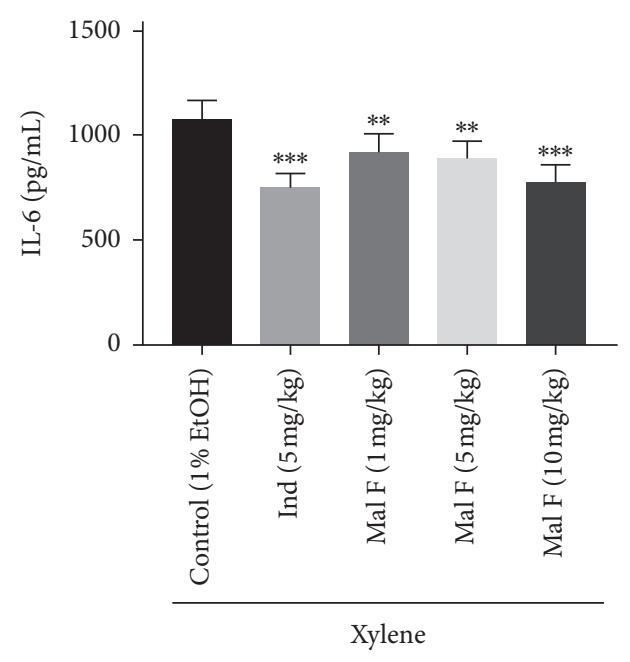

(c)

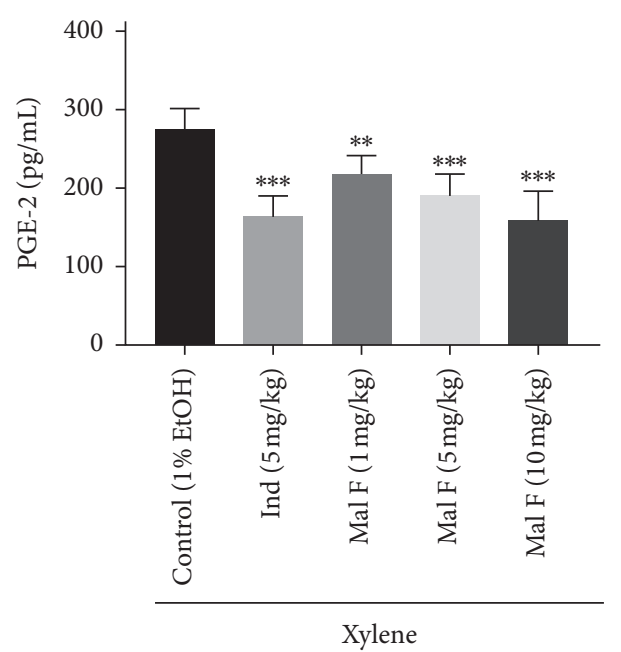

(d)

Figure 5: Maltoamide F alleviated ear edema and inflammation induced by xylene in rats. (a) Effects of Maltoamide F on xylene-induced ear edema in rats. ${ }^{*} P<0.01$ and ${ }^{* * *} P<0.001$ vs. control $(1 \% \mathrm{EtOH})$. (b) The level of TNF- $\alpha$ in homogenates of ear tissues was measured by ELISA. ${ }^{* *} P<0.01$ and ${ }^{* * *} P<0.001$ vs. control $(1 \%$ EtOH). (c) The level of IL-6 in homogenates of foot tissues was measured by ELISA. ${ }^{* *} P<0.01$ and ${ }^{* * *} P<0.001$ vs. control $\left(1 \%\right.$ EtOH). (d) The level of PGE-2 in homogenates of foot tissues was measured by ELISA. ${ }^{* *} P<0.01$ and ${ }^{* * *} P<0.001$ vs. control $(1 \% \mathrm{EtOH})$.

TABLE 1: Effect of Malyngamide F on cotton-pellet-induced granuloma in rats.

\begin{tabular}{lcc}
\hline Group & Granuloma weight $(\mathrm{mg})$ & Inhibition of granuloma (\%) \\
\hline Control $(1 \% \mathrm{EtOH})$ & $38.26 \pm 2.08$ & 67.22 \\
Indomethacin $(5 \mathrm{mg} / \mathrm{kg})$ & $12.54 \pm 1.52^{\mathrm{a}}$ & 27.73 \\
Malyngamide F $(1 \mathrm{mg} / \mathrm{kg})$ & $27.65 \pm 2.13^{\mathrm{a}}$ & 52.61 \\
Malyngamide F $(5 \mathrm{mg} / \mathrm{kg})$ & $22.46 \pm 2.35^{\mathrm{a}}$ & 41.30 \\
Malyngamide F $(10 \mathrm{mg} / \mathrm{kg})$ & $18.13 \pm 1.67^{\mathrm{a}}$ & \\
\hline
\end{tabular}

Note. a: $P<0.05$.

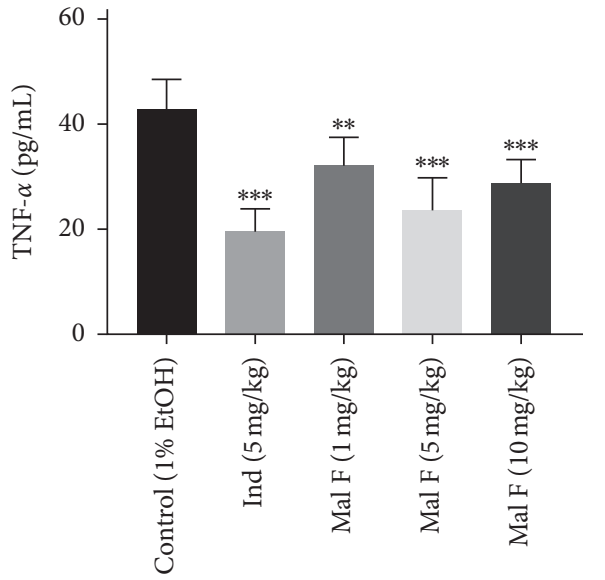

(a)

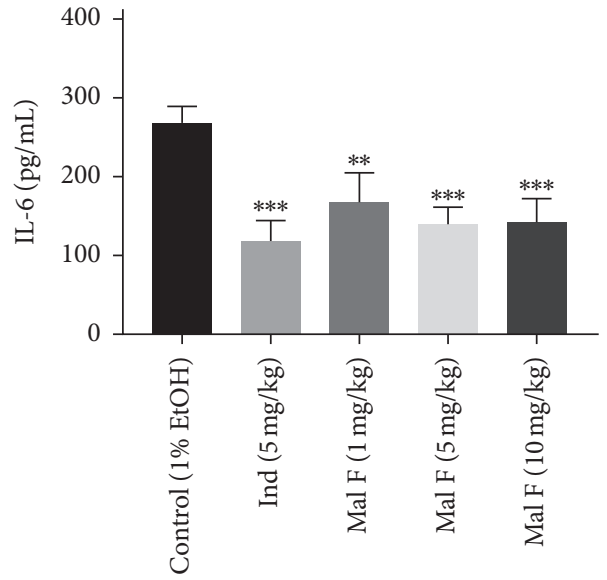

(b)

FIgUre 6: Continued. 


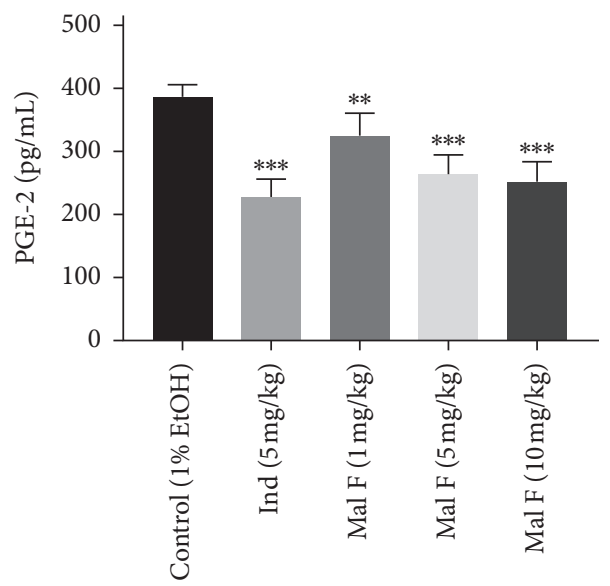

(c)

Figure 6: Maltoamide F alleviated ear edema and inflammation induced by the cotton pellet in rats. (a) The level of TNF- $\alpha$ in homogenates of cotton ball granuloma tissues was measured by ELISA. ${ }^{* *} P<0.01$ and ${ }^{* * *} P<0.001$ vs. control (1\% EtOH). (b) The level of IL-6 in homogenates of foot tissues was measured by ELISA. ${ }^{* *} P<0.01$ and ${ }^{* * *} P<0.001$ vs. control (1\% EtOH). (c) The level of PGE- 2 in homogenates of foot tissues was measured by ELISA. ${ }^{* *} P<0.01$ and ${ }^{* * *} P<0.001$ vs. control $(1 \%$ EtOH).

To our knowledge, proinflammatory cytokines such as TNF- $\alpha$ and IL- 6 exert critical roles in the inflammatory process [30]. A previous document has revealed that Malyngamide F can suppress the secretion of IL- 6 and TNF$\alpha$ in LPS-induced murine macrophages [22]. Similarly, we found that IL- 6 and TNF- $\alpha$ levels were reduced by Malyngamide $F(1 \mathrm{mg} / \mathrm{kg}, 5 \mathrm{mg} / \mathrm{kg}$, and $10 \mathrm{mg} / \mathrm{kg})$ in rat models of inflammation induced by carrageenan, formalin, AA, xylene, and cotton pellet. Based on these findings, we inferred that the anti-inflammation of Malyngamide F may be mediated by suppressing the production of IL- 6 and TNF- $\alpha$. On the other hand, convincing evidence has indicated that PGE-2 can cause abdominal constriction, and it is mostly responsible for causing inflammatory pain $[35,36]$. Several flavonoids have been demonstrated to produce analgesic action through suppression of PGE-2 synthesis $[37,38]$. In the current study, we discovered that Malyngamide $F(1 \mathrm{mg} / \mathrm{kg}, 5 \mathrm{mg} / \mathrm{kg}$, and $10 \mathrm{mg} / \mathrm{kg})$ reduced the production of PGE-2 in rat models of inflammation induced by carrageenan, formalin, AA, xylene, and cotton pellet. Thus, we speculated that Malyngamide F might have analgesic activity.

\section{Conclusions}

To conclude, the present study demonstrated that Malyngamide $\mathrm{F}$ showed potent anti-inflammatory and antinociceptive activity in rat models of inflammation. However, more biological tests and phytochemical assays are essential to verify the anti-inflammatory and analgesic activity of Malyngamide F. Moreover, further studies will be needed to explore the precise mechanisms of Malyngamide $\mathrm{F}$ on antinociceptive and anti-inflammatory activities. Overall,
Malyngamide F may be a potential chemotherapeutic agent in inflammation and pain treatment.

\section{Data Availability}

The datasets used and/or analyzed during the current study are available from the corresponding author on reasonable request.

\section{Conflicts of Interest}

The authors declare that there are no conflicts of interest regarding the publication of this article.

\section{Authors' Contributions}

Zhuocheng Li and Lei Zhang contributed equally to this work.

\section{References}

[1] R. Medzhitov, "Origin and physiological roles of inflammation," Nature, vol. 454, no. 7203, pp. 428-435, 2008.

[2] A. C. C. C. Branco, F. S. Y Yoshikawa, A. J Pietrobon, and M. N Sato, "Role of histamine in modulating the immune response and inflammation," Mediators of Inflammation, vol. 2018, Article ID 9524075, 10 pages, 2018.

[3] S. Reissmann, F. Pineda, G. Vietinghoff et al., "Structure activity relationships for bradykinin antagonists on the inhibition of cytokine release and the release of histamine," Peptides, vol. 21, no. 4, pp. 527-533, 2000.

[4] M. J. A. Saad, A. Santos, and P. O. Prada, "Linking gut microbiota and inflammation to obesity and insulin resistance," Physiology, vol. 31, no. 4, pp. 283-293, 2016.

[5] A. B. Aquino, L. H Cavalcante-Silva, C. B Matta et al., "The antinociceptive and anti-inflammatory activities of 
Aspidosperma tomentosum (Apocynaceae)," The Scientific World Journal, vol. 2013, Article ID 218627, 8 pages, 2013.

[6] L. Ulloa and K. J. Tracey, "The "cytokine profile": a code for sepsis," Trends in Molecular Medicine, vol. 11, no. 2, pp. 56-63, 2005.

[7] Z. Guo, J. Xu, J. Xia, Z. Wu, J. Lei, and J. Yu, "Anti-inflammatory and antitumour activity of various extracts and compounds from the fruits of Piper longum L." Journal of Pharmacy and Pharmacology, vol. 71, no. 7, pp. 1162-1171, 2019.

[8] F. L. Heppner, R. M. Ransohoff, and B. Becher, "Immune attack: the role of inflammation in Alzheimer disease," Nature Reviews Neuroscience, vol. 16, no. 6, pp. 358-372, 2015.

[9] J. Viola and O. Soehnlein, "Atherosclerosis-a matter of unresolved inflammation," Seminars in Immunology, vol. 27, no. 3, pp. 184-193, 2015.

[10] T. P. Erlinger, "C-reactive protein and the risk of incident colorectal cancer," Journal of the American Medical Association, vol. 291, no. 5, pp. 585-590, 2004.

[11] I. Bjarnason, J. Hayllar, A. N. d. J. Macpherson, and A. N. t. S. Russell, "Side effects of nonsteroidal anti-inflammatory drugs on the small and large intestine in humans," Gastroenterology, vol. 104, no. 6, pp. 1832-1847, 1993.

[12] G. Singh and G. Triadafilopoulos, "Epidemiology of NSAID induced gastrointestinal complications," The Journal of Rheumatology. Supplement, vol. 56, pp. 18-24, 1999.

[13] W. H. Gerwick, L. Tong Tan, and N. Sitachitta, "Nitrogencontaining metabolites from marine cyanobacteria," The Alkaloids: Chemistry and Biology, vol. 57, pp. 75-184, 2001.

[14] L. T. Tan, "Bioactive natural products from marine cyanobacteria for drug discovery," Phytochemistry, vol. 68, no. 7, pp. 954-979, 2007.

[15] H. Gross, K. L McPhail, D. E Goeger, F. A Valeriote, and W. H Gerwick, "Two cytotoxic stereoisomers of malyngamide C, 8-epi-malyngamide $\mathrm{C}$ and 8-O-acetyl-8-epi-malyngamide C, from the marine cyanobacterium Lyngbya majuscula," Phytochemistry, vol. 71, no. 14-15, pp. 1729-1735, 2010.

[16] D. R. Appleton, M. A. Sewell, M. V. Berridge, and B. R. Copp, "A new biologically active malyngamide from a New Zealand collection of the sea HareBursatella leachii," Journal of Natural Products, vol. 65, no. 4, pp. 630-631, 2002.

[17] Y. Kan, T. Fujita, H. Nagai, B. Sakamoto, and Y. Hokama, "Malyngamides $\mathrm{M}$ and $\mathrm{N}$ from the Hawaiian red AlgaGracilariacoronopifolia," Journal of Natural Products, vol. 61, no. 1, pp. 152-155, 1998.

[18] J. Orjala, D. Nagle, and W. H. Gerwick, "Malyngamide H, an ichthyotoxic amide possessing a new carbon skeleton from the Caribbean cyanobacterium Lyngbya majuscula," Journal of Natural Products, vol. 58, no. 5, pp. 764-768, 1995.

[19] L. T. Tan, T. Okino, W. H. Gerwick, and A. and B. Hermitamides, "Hermitamides A and B, toxic malyngamide-type natural products from the marine CyanobacteriumLyngbya majuscula," Journal of Natural Products, vol. 63, no. 7, pp. 952-955, 2000.

[20] F. Wan and K. L. Erickson, "Serinol-derived malyngamides from an Australian cyanobacterium," Journal of Natural Products, vol. 62, no. 12, pp. 1698-1699, 1999.

[21] K. L. McPhail and W. H. Gerwick, "Three new malyngamides from a Papua New Guinea collection of the marine cyanobacterium Lyngbya majuscula," Journal of Natural Products, vol. 66, no. 1, pp. 132-135, 2003.

[22] F. A. Villa, K. Lieske, and L. Gerwick, "Selective MyD88dependent pathway inhibition by the cyanobacterial natural product malyngamide F acetate," European Journal of Pharmacology, vol. 629, no. 1-3, pp. 140-146, 2010.
[23] K. L. Malloy, F. A. Villa, N. Engene, T. Matainaho, L. Gerwick, and W. H. Gerwick, "Malyngamide 2, an oxidized lipopeptide with nitric oxide inhibiting activity from a Papua New Guinea marine cyanobacterium," Journal of Natural Products, vol. 74, no. 1, pp. 95-98, 2011.

[24] R. D. Bruce, "An up-and-down procedure for acute toxicity testing," Toxicological Sciences, vol. 5, no. 1, pp. 151-157, 1985.

[25] K.-J. Ma, Z.-Z. Zhu, C.-H. Yu, H. Zhang, J. Liu, and L.-P. Qin, "Analgesic, anti-inflammatory, and antipyretic activities of the ethanol extract fromDesmodium caudatum," Pharmaceutical Biology, vol. 49, no. 4, pp. 403-407, 2011.

[26] Y. Tadiwos, T. Nedi, and E. Engidawork, "Analgesic and antiinflammatory activities of $80 \%$ methanol root extract of Jasminum abyssinicum Hochst. ex. Dc. (Oleaceae) in mice," Journal of Ethnopharmacology, vol. 202, pp. 281-289, 2017.

[27] H. Hosseinzadeh and H. M. Younesi, "Antinociceptive and anti-inflammatory effects of Crocus sativus L. stigma and petal extracts in mice," BMC Pharmacology, vol. 2, no. 1, p. 7, 2002.

[28] A. Sowemimo, F. Samuel, and M. S. Fageyinbo, "Anti-inflammatory activity of Markhamia tomentosa (Benth.) K. Schum. Ex Engl. ethanolic leaf extract," Journal of Ethnopharmacology, vol. 149, no. 1, pp. 191-194, 2013.

[29] R. P. Carlson, O. N.-D. Lynn, J. Chang, and A. J. Lewis, "Modulation of mouse ear edema by cyclooxygenase and lipoxygenase inhibitors and other pharmacologic agents," Agents and Actions, vol. 17, no. 2, pp. 197-204, 1985.

[30] X. Gao, Q. Sun, W. Zhang, Y. Jiang, R. Li, and J. Ye, "Antiinflammatory effect and mechanism of the spirocyclopiperazinium salt compound LXM-15 in rats and mice," Inflammation Research, vol. 67, no. 4, pp. 363-370, 2018.

[31] F. Ge, S. Xiong, F. Lin, Z. Zhang, and X. Zhang, "Highthroughput assay using a GFP-expressing replicon for SARSCoV drug discovery," Antiviral Research, vol. 80, no. 2, pp. 107-113, 2008.

[32] C. K. Glass, K. Saijo, B. Winner, M. C. Marchetto, and F. H. Gage, "Mechanisms underlying inflammation in neurodegeneration," Cell, vol. 140, no. 6, pp. 918-934, 2010.

[33] B. Siegmund and M. Zeitz, "Innate and adaptive immunity in inflammatory bowel disease," World Journal of Gastroenterology, vol. 17, no. 27, pp. 3178-3183, 2011.

[34] A. A. Adedapo, M. O. Sofidiya, P. J. Masika, and A. J. Afolayan, "Anti-inflammatory and analgesic activities of the aqueous extract ofAcacia karrooStem bark in experimental animals," Basic \& Clinical Pharmacology \& Toxicology, vol. 103, no. 5, pp. 397-400, 2008.

[35] A.-u. Kabir, M. Samad, J. Hannan, and N. D'Costa, "Investigation of the central and peripheral analgesic and anti-inflammatory activity of Draksharishta an Indian Ayurvedic formulation," Journal of Basic and Clinical Pharmacy, vol. 3, no. 4, pp. 336-340, 2012.

[36] N. Sengar, A. Joshi, S. K. Prasad, and S. Hemalatha, "Antiinflammatory, analgesic and anti-pyretic activities of standardized root extract of Jasminum sambac," Journal of Ethnopharmacology, vol. 160, pp. 140-148, 2015.

[37] M. L. Nesa, S. M. S. Karim, K. Api et al., "Screening of Baccaurea ramiflora (Lour.) extracts for cytotoxic, analgesic, anti-inflammatory, neuropharmacological and antidiarrheal activities," BMC Complementary and Alternative Medicine, vol. 18, no. 1, p. 35, 2018.

[38] L. Nesa, S Munira, S Mollika et al., "Evaluation of analgesic, anti-inflammatory and CNS depressant activities of methanolic extract of Lawsonia inermis barks in mice," Avicenna Journal of Phytomedicine, vol. 4, no. 4, pp. 287-296, 2014. 